\title{
Save the poor, shoot some bankers
}

\author{
David Zetland
}

Received: 18 November 2009 / Accepted: 18 August 2010 / Published online: 1 September 2010

(C) The Author(s) 2010. This article is published with open access at Springerlink.com

\begin{abstract}
Bilateral or multilateral organizations control about $90 \%$ of official overseas development assistance (ODA), much of which is wasted. This note traces aid failure to the daisy chain of principal-agent-beneficiary relationships linking rich donors to aid bureaucrats to poor recipients. Waste results when aid middlemen (un)intentionally misdirect ODA. Waste can be reduced by clarifying domestic goals for ODA, using fewer middlemen with greater intrinsic motivation, empowering recipients, and/or replacing bureaucracy with markets.
\end{abstract}

Keywords Aid · Principal-agent · Asymmetric information · Intrinsic motivation · Public choice

JEL Classification F35 · O19

\section{Prologue}

I'm sitting in El Parque Central of Estelí, Nicaragua. I just visited the Galeria Heroes y Martires, and-feeling guilty that America helped the Contra rebels who killed so many of these martyrs-I want to help.

Nicaraguan life expectancy is 73 years. Per capita income is $\$ 2,600$ (PPP). Adult illiteracy is $22 \%$. Nicaragua sits in 124th place out of 182 countries in the Human Development Index, flanked by Egypt and Botswana (UNDP 2009).

These poor people need me, and I've got $\$ 20$ in my pocket.

Maybe I should give the money to the guy sleeping on the bench? No, he has a cell phone. Perhaps the girl—she looks 14-with a kid? No, she has a husband-and they're smiling, dammit. The homeless guy? No, he can't tie his pants.

I could give my money to the government, but Daniel Ortega (who fought the Contras in the 80s and was elected President in 2006) is lurching towards a Cuban-style dictatorship.

D. Zetland $(\bowtie)$

Department of Agricultural \& Resource Economics, University of California, Berkeley, CA, USA

e-mail: dzetland@gmail.com 
Maybe I should give my money to the experts? Perhaps the EU-funded Campaña contra la Explotación Sexual Commercial? the Centro Cultural Nicaragüense Norteamericano? the Catholic church? No, I'm worried that my money will pay for a bureaucrat's lunch, the distribution of "American Idol," or-worse-another coat of paint on that huge empty cathedral. I want to get the biggest bang for my buck, but I have no idea of how to solve this optimization problem.

I give up, spending my money on a good meal and clean room. Aid is hard.

\section{Helping the poor?}

In 2008, official Overseas Development Assistance (ODA) to developing countries was $\$ 146$ billion. Of this, $9 \%$ went to humanitarian relief/food aid and $2 \%$ went to non-governmental organizations. Sixty-four percent went to bilateral agencies like USAID; multi-lateral agencies like the World Bank got the remaining $25 \%{ }^{1}$

Unfortunately, ODA rarely produces development (Easterly 2001, 2006, 2009). Why not? Donors need to choose the right place for the right project. Then they need to get the right people-middlemen - to work as their agents. These middlemen form a supply chain that stretches around the globe, linking numerous agents with various skills and concerns on projects that are usually unique, rarely priced and often understood only by a few. A specification of the principal-agent relationships in ODA would probably produce the most complex structural model in the world, and we probably couldn't even use it. For this note we will simplify these numerous middlemen into a single middleman who sits between the donor (taxpayer) and recipient (poor person) in a principal-agent-beneficiary model that we won't try to solve, since that would require that variables and parameters be specified.

Note that the ODA principal's role is split in two, with rich taxpayers as donors and poor recipients as recipients. ${ }^{2}$ This division makes it much harder to deal with agents, either when selecting middlemen (adverse selection) or monitoring their activities (moral hazard). That's because the donor's costly effort to select and monitor middlemen creates benefits for others, the recipients. So the donor faces weak incentives (effort without benefits), stronger asymmetric information (results in a distant place), and weaker feedback (recipients who do not know what's supposed to happen or how to give feedback without facing punishment).

But before we get into the factors that determine middleman success or failure, we need to address one question: Why don't donors just send cash? Probably because they want something other than "a world without poverty." Scholars have argued that ODA is really about domestic politics (Vaubel 1986; Dreher et al. 2008), ${ }^{3}$ paternalistic charity (Kruse et al. 1997), or extending domestic bureaucracy overseas. ${ }^{4}$

\footnotetext{
${ }^{1}$ http://stats.oecd.org/wbos/default.aspx ?DatasetCode=TABLE1, accessed on 3 July 2010. NGOs also receive an unknown amount of private contributions.

${ }^{2}$ Nielson and Tierney (2003) explore the principal-agent dynamics among governments (both within a government and across multiple governments) as principals and the World Bank as an agent. Cooperation among principals was possible, but it took ten years for donors to convince the Bank to drop policies promoting Amazonian deforestation.

${ }^{3}$ Corruption may not matter for US or bilateral aid, but it does for Scandinavian countries and multilateral agencies (Alesina and Weder 2002; Amegashie et al. 2007).

${ }^{4}$ Aid-as-manipulation can be sold to citizens under a Baptists and Bootleggers paradigm (Yandle 1983). The Bootleggers who want to extend their power abroad are supported by Baptists who insist that governments do something-even if it's ineffective (Cowen 2006). For example. Bono demands that rich countries send $0.7 \%$ of GDP; GW Bush agrees - and directs military aid to strategic allies (Columbia, Pakistan) or ineffective family planning programs that emphasize abstinence over condoms.
} 
Table 1 Middlemen quality is composed of knowledge and care

\begin{tabular}{lll}
\hline Knowledge & High care & Low care \\
\hline High & Experienced aid worker & Corrupt local official \\
Low & Enthusiastic volunteer & Bureaucrat on a junket \\
\hline
\end{tabular}

\section{A daisy chain of agents}

Assume (contrary to the public choice literature) that donors want to maximize effective aid and minimize middleman waste from theft, mismanagement, excess bureaucracy, distorted incentives, cultural imperialism, and other distractions. What determines waste? Start with a simple production function that takes donor money into one end and spits out a finished product - development - at the other. What does the function contain? A middleman whose quality and effort can turn money into development or divert it to waste.

Unusually, the quality of an ODA middleman is based on more than just knowledge. The middleman has more discretion on where to put his effort than, say, a car mechanic. The mechanic cannot put great effort into painting your car when it's got an oil leak, but the middleman can put great effort into painting billboards when you have to run an AIDS awareness campaign. A distant middleman has to be trusted to choose the right program and path from a set of choices that's unknown to the donor. So the problem does not really involve moral hazard (effort) as much as adverse selection (quality).

It helps to break this middleman quality into two pieces: Knowledge-knowing how to listen to local people and respond to their needs with appropriate measures that consider institutions (culture, history, and norms) and avoid past mistakes-corresponds with the middleman's ability to do the job. Care matches his desire to do it well, due to professionalism, identity and/or altruism; see, respectively, Wilson (1989), Akerlof and Kranton (2000), Fehr and Fischbacher (2002). Care provides the intrinsic motivation to get the job done well, regardless of extrinsic motivation or monitoring. Care is the special sauce that turns failure into success - and vice versa. Care is harder to see or measure than knowledge, but it's more important. An ignorant middleman who cares can still succeed, but a knowledgable one who does not care usually fails (Reinikka and Svensson 2004a). ${ }^{5}$ (Care does not assure success, since many factors - known and unknown unknowns - can frustrate a project. And it will be hard to know if the middleman helped or hindered that failure.)

We can categorize middleman quality in a two-by-two grid of high/low care and knowledge-see Table 1. In the high-care, high-knowledge square, you might find an experienced aid worker who cares about results. In the low-care, low-knowledge square, you may get a bureaucrat on a foreign junket who cares more about happy hour and the price of an "overnight friend." In the off-diagonal squares are the high-care, low-knowledge volunteer whose good ideas may not match local traditions or technological capabilities and low-care, high-knowledge local official who knows what needs to be done but really prefers to steal office supplies.

\footnotetext{
${ }^{5}$ Burt (2008) describes how Engineers without Borders deserted their "mission" (community showers) and delivered what locals wanted (water conveyance and storage). Woodberry and Shah (2004) argue that Protestant missionaries' promotion of literacy (to read the Bible) enhanced development by facilitating civic discourse. This unintended positive outcome was not associated with Catholic missionaries who supported incumbent power structures.
} 
Adverse selection problems cannot easily be solved using reputation, repeated games, or efficiency wages because it's hard to connect inputs and outputs, bespoke projects can take years, and exogenous factors are significant. Reputation is not easy to discover-for example, when the donor is starting in a country, on a project, or with new staff. A repeated game doesn't mean you get to change middlemen or learn anything from year-to-year. Staff might have tenure; a local monopolist may control transport, communication or security. Monitoring across continents, through chains of middlemen with joint responsibilities make it hard to know who did what or how those inputs affected outcomes, whatever those may be and whoever they affected (Ostrom et al. 2001; Martens et al. 2002). These information problems make it difficult to implement efficiency wages with a credible threat of punishment. (Even worse, high wages may attract middlemen who need extrinsic motivation to take the job but lack the intrinsic motivation-care-to do it.)

Monitoring for effort is possible but costly. Aid goes to activities that are hard to measure, in places that are geographically and culturally distant. Further, the asymmetry of monitoring costs to donors and aid benefits to recipients weakens donor incentives. Recipients are often powerless to monitor or punish middlemen. They will not even complain, since the middleman's job security and monopoly power allow him to ignore or even punish nosy or noisy recipients. ${ }^{6}$ Robert W. Sarnoff quipped that "finance is the art of passing currency from hand to hand until it finally disappears." His observation applies to ODA, where the principal is split into a donor and recipient who do not talk, the actions of many middlemen are hard to trace, and it's quite common for funds to go from here to there, producing piles of paper and a few mansions but zero or even negative development (Easterly 2009). ${ }^{7}$

\section{Discussion and recommendations}

Foreign aid might be defined as a transfer of money from poor people in rich countries to rich people in poor countries

Douglas Casey (1992)

The current ODA system may be ineffective because donors are pursuing domestic goals; middlemen have low quality, shirk or dissipate responsibility within a chain; ODA is pushed at passive recipients; and/or bureaucratic command and control dominates. ODA would be more effective if aid was directed by a few high-quality middleman who were easy to monitor and who worked on projects that recipients designed and monitored. These changes may upset nationalists who think their money entitles them to lord over others but not those who want to help poor foreigners.

\footnotetext{
${ }^{6}$ Ostrom et al. (2001) describe how this works — see Murrell (2002) for a theoretical treatment—and find that middlemen serve the donor (moving money, issuing reports) more than the recipient (putting the money to good use). They recommend that recipients be given more power over middlemen, to clarify who gets priority.

${ }^{7}$ Governments receiving ODA can avoid the you-pay-taxes-we-provide-services exchange with citizens, just as resource wealth-oil, diamonds_-does (Mehlum et al. 2006). Economides et al. (2008) show that aid increases rent-seeking in countries with large public sectors. Chong et al. (2009) show that aid can increase growth that favors the rich.
} 
Let's look at some ways to address current problems:

Real Aid: ODA needs to be divided into "development" and "strategic" categories to clarify whether the beneficiary is, respectively, foreign or domestic. This action would upset government officials who prefer to mingle these goals, so NGOs may need to clarify the difference. Strategic ODA already exists (military cooperation with foreign governments for domestic purposes), so these categories are not novel.

Middlemen: First, reduce their number. Shortening the supply chain will save money and focus attention on survivors (Reinikka and Svensson 2004b). Second, apply stronger quality filters to avoid adverse selection by hiring people who have demonstrated levels of "care" (Peace Corps volunteers, missionaries or NGO staff who have worked for several years at local salaries), linking wages to performance (Reinikka and Svensson 2004b), and/or paying local wages. ${ }^{8}$ Third, weaken the market power of middlemen. Although competing middlemen can crowd out good projects or give monopsony power to recipients (Platteau and Gaspart 2005; Werker and Ahmed 2008), benchmarking and community discipline can reduce this problem. NGOs are taking market share from official agencies (Masud and Yontcheva 2005) because they compete with each other, emphasize intrinsic compensation, and modify their structure and alliances for each delivery project. Competitive bidding and benchmarking among bilateral and multilateral agencies would make them compete on results instead of inputs. ${ }^{9}$ Losers should be shut down and their budgets redirected to winners.

Empowerment: Give ODA recipients (not their governments!) more power to pull projects to themselves-replacing big pushes and central planning with recipients' goals and monitoring (Barr et al. 2003; Easterly 2006; Bjorkman and Svensson 2009). Sirolli (1999) describes how real, durable development requires flexibility in working with recipient needs. "Cash-on-delivery" aid facilitates those methods, by allowing locals to find the right path to a goal set by the donor (Birdsall and Savedoff 2009).

Markets: Bureaucracies everywhere suffer a knowledge problem that is particularly acute in ODA - due to cultural divides, missing data, strained logistics, vague goals, and useless benchmarks (Hayek 1945; Prokopijevic 2006; Easterly 2009). Jeff Sachs advocates the extreme solution-moving poor people to Millennium Villages where life has been redesigned by "expert" outsiders. Bill Easterly (2006) advocates a humbler, trial-and-error approach where many searchers try numerous ideas. ODA fails for the same reason that the USSR did, and it can succeed with a little more capitalism (Barder 2009). Note that markets per se may produce more development than any aid program. Don't waste money on command and control interventions; use it to remove barriers, bureaucrats, and rules that inhibit freedom and development (Sen 1999).

Was I wrong to redirect my $\$ 20$ from charity to room and board? No. Gifts are neither necessary nor sufficient for development. My \$20 rewarded locals who were doing good work and gave them the purchasing power to reward others providing useful goods and

\footnotetext{
${ }^{8}$ Proponents of high wages claim they attract quality people (Gagliarducci and Nannicini 2008) and lower shirking (efficiency wages). Opponents say enhanced extrinsic incentives are ineffective while structural problems (daisy chain, passive recipients) persist (Ostrom et al. 2001).

${ }^{9}$ Dadush (2009) and Bruckner (2010) call attention to NGOs and ODAs that hide expenses and salary structures. In my own examination IRS 990s for the US offices of OxFam and Medicins sans Frontiers, I found that OxFam allocated a relatively larger share of salary expenses to "program spending" (aid). Since US-branches only raise money to send abroad, it appears that OxFam reclassifies expenses under program spending to make their overhead (fundraising and management) look smaller.
} 
services. That's what development is all about—feedback, incentives and institutions that minimize the friction in delivering the goods that citizens want (North 2005). That's how we've succeeded, and that's how others can.

Acknowledgements Thanks to Carew Boulding, Rosa Català-Luque, Avinash Dixit, Diego Gambetta, QQ Huang, Gorm Kipperberg, Johannes Münster, Rich Sexton, Mary Shirley and Stergios Skaperdas and two referees for their helpful comments. Special thanks to Aslihan Arslan, Steve Boucher, Natalia Cruz, Alex McCalla, Jens Prüfer, Robert Tulip and Treena Wu for long discussions, and the many strangers who explained the rules of the game to me during my travels in 80 countries. This note was originally titled "Don't Shoot the Middleman: Explaining Efficiency in International Aid."

Open Access This article is distributed under the terms of the Creative Commons Attribution Noncommercial License which permits any noncommercial use, distribution, and reproduction in any medium, provided the original author(s) and source are credited.

\section{References}

Akerlof, G. A., \& Kranton, R. E. (2000). Economics and identity. Quarterly Journal of Economics, 115(3), $715-53$

Alesina, A., \& Weder, B. (2002). Do corrupt governments receive less foreign aid? American Economic Review, 92(4), 1126-1137.

Amegashie, J. A., Ouattara, B., \& Strobl, E. (2007). Moral hazard and the composition of transfers: theory with an application to foreign aid. MPRA Paper, 3158.

Barder, O. (2009). Beyond planning: markets and networks for better aid. Center for Global Development Working Paper, 185.

Barr, A., Lindelow, M., \& Serneels, P. (2003). To serve the community or oneself: the public servant's dilemma. Center for Study of African Economies Working Paper, 11.

Birdsall, N., \& Savedoff, W. D. (2009). Cash on delivery: a new approach to foreign aid with an application to primary schooling. Washington: Center for Global Development.

Bjorkman, M., \& Svensson, J. (2009). Power to the people: evidence from a randomized field experiment of a community-based monitoring project in Uganda. Quarterly Journal of Economics, 124(2), 735-769.

Bruckner, T. (2010). Secret NGO budgets: publish what you spend. www.aidwatchers.com, 24 May.

Burt, V. (2008). Careers: engineering a cause. Machine Design, 7 Aug. http://machinedesign.com/article/ careers-engineering-a-cause-0807.

Chong, A., Gradstein, M., \& Calderon, C. (2009). Can foreign aid reduce income inequality and poverty? Public Choice, 140(1), 59-84.

Cowen, T. (2006). Investing in good deeds without checking the prospectus. New York Times, 15 Jun:C-3.

Dadush, S. (2009). Profiting in (RED): innovative development finance or a symptom of inadequate regulation? Institute for International Law and Justice Working Paper.

Dreher, A., Nunnenkamp, P., \& Thiele, R. (2008). Does US aid buy UN general assembly votes? A disaggregated analysis. Public Choice, 136(1), 139-164.

Easterly, W. (2001). The elusive quest for growth: economists' adventures and misadventures in the tropics. Cambridge: The MIT Press.

Easterly, W. (2006). The white man's burden: why the west's efforts to aid the rest have done so much ill and so little good. New York: Penguin Press.

Easterly, W. (2009). Can the West save Africa? Journal of Economic Literature, 47(2), 373-447.

Economides, G., Kalyvitis, S., \& Philippopoulos, A. (2008). Does foreign aid distort incentives and hurt growth? Theory and evidence from 75 aid-recipient countries. Public Choice, 134(3), 463-488.

Fehr, E., \& Fischbacher, U. (2002). Why social preferences matter-the impact of non-selfish motives on competition, cooperation and incentives. Economic Journal, 112(478), C1-C33.

Gagliarducci, S., \& Nannicini, T. (2008). Do better paid politicians perform better? Disentangling incentives from selection. IZA Discussion Paper, 4400.

Hayek, F. A. (1945). On the use of knowledge in society. American Economic Review, 35(4), 519-530.

Kruse, S.-E., Kyllönen, T., Ojanperä, S., Riddell, R. C., \& Vielajus, J. (1997). Searching for impact and methods. NGO Evaluation Synthesis Study, OECD/DAC Expert Group on Evaluation.

Martens, B. (2002). Introduction. In Martens, B., Mummert, U., Murrell, P., \& Seabright, P. (Eds.), The Institutional Economics of Foreign Aid (pp. 1-33). Cambridge: Cambridge University Press. Chapter 1. 
Masud, N., \& Yontcheva, B. (2005). Does foreign aid reduce poverty? Empirical evidence from nongovernmental and bilateral aid. IMF Working Paper, 05/100.

Mehlum, H., Moene, K., \& Torvik, R. (2006). Institutions and the resource curse. Economic Journal, 116, $1-20$.

Murrell, P. (2002). The interaction of donors, contractors and recipients. In Martens, B., Mummert, U., Murrell, P., \& Seabright, P. (Eds.), The Institutional Economics of Foreign Aid (pp. 69-111). Cambridge: Cambridge University Press. Chapter 3.

Nielson, D. L., \& Tierney, M. J. (2003). Delegation to international organizations: agency theory and World Bank environmental reform. International Organization, 57(02), 241-276.

North, D. C. (2005). Understanding the process of economic change. Princeton: Princeton University Press.

Ostrom, E., Gibson, C., Shivakumar, S., \& Andersson, K. (2001). Aid, incentives, and sustainability an institutional analysis of development cooperation. Sida Studies in Evaluation 02/01, Sida, Department for Evaluation and Internal Audit.

Platteau, J. P., \& Gaspart, F. (2005). Disciplining local leaders in community-based development. Working Paper.

Prokopijevic, M. (2006). Why foreign aid fails. ICER Working Paper, 19/2006.

Reinikka, R., \& Svensson, J. (2004a). Local capture: evidence from a central government transfer program in Uganda. Quarterly Journal of Economics, 119(5), 679-705.

Reinikka, R., \& Svensson, J. (2004b). Working for god? CEPR Discussion Paper, 4214.

Sen, A. (1999). Development as freedom. New York: Alfred A. Knopf.

Sirolli, E. (1999). Ripples from the Zambeizi. Gabriola Island (BC): New Society Publishers.

UNDP (2009). Human development report. United Nations Development Program.

Vaubel, R. (1986). A public choice approach to international organization. Public Choice, 51(1), 39-57.

Werker, E., \& Ahmed, F. Z. (2008). What do nongovernmental organizations do? Journal of Economic Perspectives, 22(2), 73-92.

Wilson, J. Q. (1989). Bureaucracy: what government agencies do and why they do it. New York: Basic Books.

Woodberry, R. D., \& Shah, T. S. (2004). The pioneering protestants. Journal of Democracy, 15(2), 47-61.

Yandle, B. (1983). Bootleggers and baptists: the education of a regulatory economist. Regulation, 7(3), 12. 